\title{
Salicylic acid and its method of application affect germination and vigor in bell pepper seedlings under salt stress
}

Sebastião de Oliveira Maia Júnior, Jailma Ribeiro de Andrade, Ronaldo do Nascimento, Robson Felipe de Lima, Elka Costa Santos Nascimento, Mateus Costa Batista, Rafaela Félix Basílio Guimarães, Carlos Vailan de Castro Bezerra

Universidade Federal de Campina Grande - UFCG, Unidade Acadêmica de Engenharia Agrícola - UAEAg, Centro de Tecnologia e Recursos Naturais - CTRN, PB. E-mail: juniormaiagrari@hotmail.com

\begin{abstract}
This study investigated the effect of two salicylic acid application methods (seed immersion and wetting) on the germination and growth characteristics of cv. All Big bell pepper seedlings exposed to 0 or $100 \mathrm{mM}$ of $\mathrm{NaCl}$. The experiment was conducted in a Biochemical Oxygen Demand (BOD) incubator, using a completely randomized design with eight treatments (immersion in salicylic acid or distilled water and wetting with salicylic acid or water, in conjunction with 0 or $100 \mathrm{mM}$ of $\mathrm{NaCl}$ ) and four repetitions. The results indicated that under non-saline conditions, wetting with salicylic acid (SA) inhibited germination and seedling length, whereas $\mathrm{NaCl}$ stress reduced the germination, growth, total dry weight and vigor of seedlings. However, SA application, especially by wetting, mitigated the toxic effects of $\mathrm{NaCl}$ in bell pepper seedlings, improving relative water content and radicle length, as well as total length, dry weight and vigor. This study highlights the potential benefits of SA, particularly when applied via wetting, in attenuating phytotoxicity caused by $\mathrm{NaCl}$ stress and its effect on the germination, growth and vigor of bell pepper seedlings.
\end{abstract}

Keywords: Capsicum annuum L.; membrane permeability; $\mathrm{NaCl}$; seedling growth; vigor index.

\section{Ácido salicílico e sua forma de aplicação alteram a germinação e o vigor de plântulas de pimentão sob estresse salino}

\section{Resumo}

Os efeitos do ácido salicílico em duas formas de aplicação (imersão ou umedecimento das sementes) foram investigados nas características de germinação e crescimento de plântulas de pimentão cv. All Big sob 0 ou $100 \mathrm{mM}$ de $\mathrm{NaCl}$. Um experimento em câmara de germinação foi realizado em delineamento inteiramente casualizado com oito tratamentos (imersão das sementes em AS ou água destilada e umedecimento com AS ou água, associados às concentrações de 0 ou $100 \mathrm{mM}$ de $\mathrm{NaCl}$ ), cada um com quatro repetições. Os resultados indicaram que em condição não salina, o AS no umedecimento inibiu a germinação e o comprimento da plântula, enquanto o estresse de $\mathrm{NaCl}$ reduziu a germinação, o crescimento, a produção total de massa seca e o índice de vigor das plântulas. No entanto, a aplicação de AS, sobretudo no umedecimento atenuou os efeitos tóxicos do $\mathrm{NaCl}$ nas plântulas de pimentão melhorando o conteúdo relativo de água, o comprimento da radícula, bem como o comprimento e massa seca total e índice de vigor das plântulas. Este estudo destaca potenciais efeitos benéficos de AS, principalmente aplicado no umedecimento, na atenuação da fitotoxicidade do estresse de $\mathrm{NaCl}$ sobre a germinação, crescimento e vigor de plântulas de pimentão.

Palavras-chave: Capsicum annuum L.; comprimento de plântulas; índice de vigor; $\mathrm{NaCl}$; permeabilidade de membranas. 


\section{Introduction}

Salinity is a serious global problem that threatens crop yields and food production. It affects millions of hectares of land worldwide, increasing by $10 \%$ every year, and is expected to reach $50 \%$ of all arable land by 2050 (BARTELS; SUNKAR, 2005; SHRIVASTAVA; KUMAR, 2015). Both the osmotic and ionic factors of salt stress are harmful to plants. The former is the result of a high solute concentration in the soil solution, causing drought stress due to decreased osmotic potential, and the latter is caused by high $\mathrm{Na}^{+}$and $\mathrm{Cl}^{-}$levels, as well as changes in the $\mathrm{K}^{+} / \mathrm{Na}^{+}$ratio and nutrient uptake (WILLADINO; CAMARA, 2010).

The effects of salt stress that lead to lower crop yields generally begin during germination, when a variety of metabolic reactions occur (KHAN et al., 2015). In this stage, in addition to lowering the potential gradient between the seed surface and surrounding media, salts also act as stressors and induce membrane degradation via the hyperaccumulation of toxic ions in seedlings, compromising cell membranes (MISRA; SAXENA, 2009; TONEL et al., 2013; JAYAKANNAN et al., 2015; KHAN et al., 2019).

A number of strategies improve plant growth and yield under salt stress, including genetic modifications and/or the use of tolerance inducers such as salicylic acid (KHAN et al., 2015). Salicylic acid (SA) is an endogenously synthesized phenolic compound found in plants. Like a growth promoter, it plays an important role in physiological processes (JAYAKANNAN et al., 2015; KHAN et al., 2015), including improving germination and seedling growth under salt stress (TONEL et al., 2013; JINI; JOSEPH, 2017), increasing membrane stability (HAYAT et al., 2012) and reducing the accumulation of toxic ions such as $\mathrm{Na}^{+}$and $\mathrm{Cl}^{-}$, thereby minimizing damage (JINI; JOSEPH, 2017) and enhancing the growth, biomass production (MISRA; SAXENA, 2009) and vigor of seedlings (ALAMRI et al., 2018). However, despite the evidence of SA mitigating salt stress in different plant species, its effects vary depending on how it is used.

In this context, given the lack of research on SA-related salt tolerance in bell peppers, the present study is an important contribution to improving bell pepper farming, particularly seedling germination and vigor. Our hypothesis is that the SA attenuates the effects of salinity in bell pepper seeds, increasing the germination percentage, the growth and the seedling vigor index, but it can vary with the form of application. As such, the aim of this study was to assess the role of SA, applied using two different methods, in attenuating the effects of salt stress on the germination, growth and vigor index of bell pepper seedlings.

\section{Material and methods}

The study was conducted in the Plant Physiology Laboratory of the Agricultural Engineering Unit at the Federal University of Campina Grande from June to July, 2019. The germination of cv. All Big bell peppers was analyzed using two different methods to apply $1.0 \mathrm{mM}$ of salicylic acid, namely immersing seeds in SA or deionized water or wetting them with the same substances on Germtest ${ }^{\circledR}$ paper, in conjunction with 0 or $100 \mathrm{mM}$ of $\mathrm{NaCl}$, with four repetitions each. In the immersion treatment, seeds were immersed in SA or deionized water for 60 minutes, whereas wetting was performed after the seeds were placed on Germtest ${ }^{\circledR}$ paper, in accordance with the respective treatments.

The experiment consisted of eight treatments in a completely randomized design, with four repetitions involving 25 seeds each. The treatments were designated as IWO: immersion in water without $\mathrm{NaCl}$; ISAO: immersion in salicylic acid without $\mathrm{NaCl}$; WWO: wetting in water without $\mathrm{NaCl}$; WSAO: wetting in salicylic acid without $\mathrm{NaCl}$; IW100: immersion in water with $\mathrm{NaCl}$; ISA100: immersion in salicylic acid with $\mathrm{NaCl}$; WW100: wetting in water with $\mathrm{NaCl}$; WSA100: wetting in salicylic acid with $\mathrm{NaCl}$.

The seeds were placed on two sheets of Germtest ${ }^{\circledR}$ paper and covered with another sheet. These were then wetted at twice their dry weight with the solutions stipulated for each treatment. The sheets were then placed in polypropylene trays, separated by treatment, and left to germinate in a Biochemical Oxygen Demand (BOD) incubator at $25 \stackrel{\circ}{ } \mathrm{C} \pm 1$ under a 12 hour photoperiod, for 14 days.

The germinated seeds were counted at 7 and 14 days (BRASIL, 2009), considering those with a radicle at least $2 \mathrm{~mm}$ long, in order to determine the first count and germination percentage, respectively, in accordance with the methodology proposed by Maguire (1962).

The relative water content and electrolyte leakage from seedlings were assessed after germination. Electrolyte leakage (EL) was 
determined in accordance with Chu et al. (2016), with slight changes. Samples of two seedlings were washed with distilled water, placed in glass test tubes and incubated in distilled water at 25 ${ }^{\circ} \mathrm{C}$ for 2 hours. Next, electrical conductivity was measured (C1) using an electrical conductivity meter. The samples were then heated at 80 ㅇ for $30 \mathrm{~min}$ and electrical conductivity was measured after cooling (C2). EL was calculated using the formula $\mathrm{EL}=\mathrm{C} 1 / \mathrm{C} 2 \times 100$.

Relative water content (RWC) was obtained using plumule and radicle samples from each repetition (FW) that were left to floated in distilled water for $24 \mathrm{~h}$, after which turgor weight (TW) was determined at room temperature. Dry weight (DW) was obtained after drying the plant material at $80^{\circ} \mathrm{C}$ for $24 \mathrm{~h}$ (LOTFl et al., 2019) and RWC calculated as RWC $=(F W-D W) /(T W-D W) \times$ $100 \%$.

Shoot, radicle and total seedling length were also assessed and the results expressed in $\mathrm{cm}$. Following these measurements, the different plant parts were dried in a forced air oven at 80 o $C$ for 48 hours and then weighed, with the results expressed in mg per seedling. Seed vigor indices I and II were calculated based on the germination, seedling length and dry weight results, in line with Naguib (2019).

The data were submitted to analysis of variance using the F-test and, in the event of significance between treatments, means were compared by Tukey's test at $5 \%$ probability $(p<0.05)$. Principal component analyses (PCA) were performed to obtain a broad characterization of SA applications under saline and non-saline conditions.

\section{Results and discussion}

The effects of salinity were evident for total seedling length, whereas those of salicylic acid application were most visible for root length (Figure 1).

Figure 1. Effect of two salicylic acid $(1 \mathrm{mM})$ application methods on the germination and establishment of bell pepper seedlings under $\mathrm{NaCl}$ concentrations (0 and $100 \mathrm{mM}$ ). IW: immersion in deionized water; ISA: immersion in salicylic acid; WW: wetting with deionized water; WSA: wetting with salicylic acid. Campina Grande-PB, Brazil, 2019.

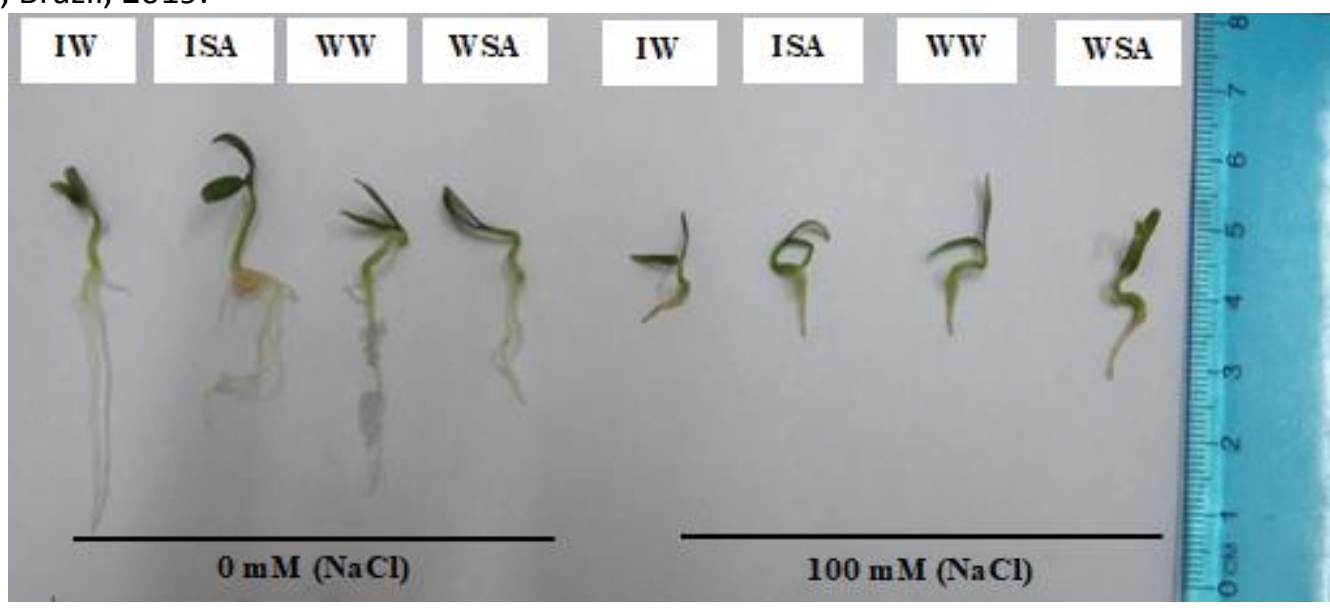

Bell pepper seeds treated via the different SA application methods varied only in the nonsaline treatment, in which immersed seeds exhibited greater germination at first count, with no difference between technique in the saline treatment (Figure 2A). The highest germination percentage (13.7\%) was recorded for seed immersion under saline when compared to nonsaline conditions (Figure 2B), with no difference between SA application methods in the latter. 
Figure 2. First count (A), germination percentage (B), relative water content (C) and electrolyte leakage (D) in bell pepper seedlings submitted to different SA application methods and $\mathrm{NaCl}$ concentrations. IW: immersion in water, ISA: immersion in salicylic acid, WW: wetting with water, SW: wetting with $\mathrm{NaCl}, \mathrm{WSA}$ : wetting with salicylic acid and SW+AS: wetting with $\mathrm{NaCl}$ and salicylic acid. Vertical bars in the columns represent the standard error $(n=4)$. Different upper case letters indicate significant differences between $\mathrm{NaCl}$ concentrations within each method and lower case letters significant differences between methods within each saline concentration. Campina Grande-PB, Brazil, 2019.
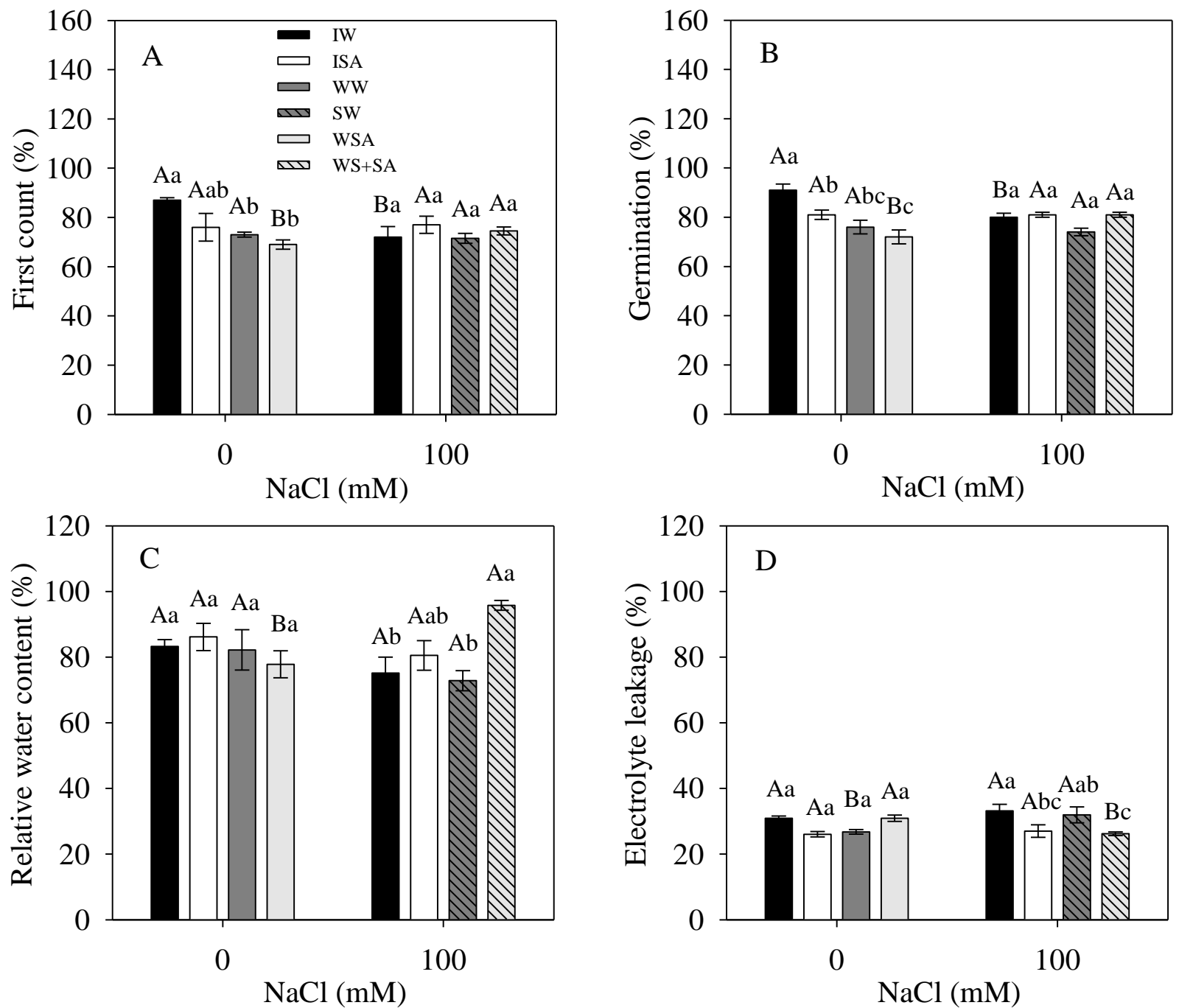

Salicyclic acid (SA) functions as a good salt tolerance inducer during germination and seedling development in a number of plant species, including rice (JINI; JOSEPH, 2017; KHAN et al., 2019), chickpea (GROVER et al., 2015), lentil (MISRA; SAXENA, 2009) and maize (TONEL et al., 2013). In the present study, the effects of SA on bell pepper germination were more pronounced in the absence of salt stress, unlike other investigations in which germination improved under saline conditions, such as that by Misra and Saxena (2009). The authors found that SA increased germination in lentils exposed to salt stress, both at first count and final

germination percentage, indicating that SA acted as a salt tolerance inducer from the onset of germination. These results may be due to the plant species itself, the 4-hour seed immersion time when compared to the 1 hour used here, or the SA concentration applied. In a study with two rice cultivars, an increase in salinity from 100 to $400 \mathrm{mmol}$ of $\mathrm{NaCl}$ inhibited the germination percentage, whereas combining these saline levels with $1.0 \mathrm{mmol}$ of $\mathrm{SA}$ improved germination, especially at the lowest salt concentration (JINI; JOSEPH, 2017). In chickpea, Grover et al. (2015) used SA concentrations of 1.5 and $3.0 \mathrm{mg}$ and found that the highest dose 
reduced germination in relation to the lowest at all the saline levels tested. The authors also reported germination inhibition with a rise in SA concentration under non-saline conditions, as observed in our study. As such, both the concentration (JINI; JOSEPH, 2017) and exposure time to salicylic acid influence germination, as observed in bell pepper seeds wetted with SA alone. Additionally, most reports indicate that SA has a more pronounced effect only on plants under stress (KHAN et al., 2015).

There was no variation in relative water content (RWC) under saline conditions; however, at $100 \mathrm{mM}$ of $\mathrm{NaCl}$, wetting with SA obtained the highest RWC despite not differing from immersion in SA, reaching $31.5 \%$ higher than wetting with salt water (Figure 2C). Salinity reduces turgidity in plants submitted to stress; however, this response depends on plant characteristics such as the type of organ or tissue, development stage and genotype (WILLADINO; CAMARA, 2010). In adult tomato plants, salinity lowered the relative water content by around 25\% (TUNA et al., 2007). In young Brassica carinata plants the decline was approximately 27\% (HUSEN et al., 2018), whereas the water content of lentil seedlings, determined based on fresh weight, fell by only $18.5 \%$ when exposed to $100 \mathrm{mM}$ of $\mathrm{NaCl}$ (MISRA; SAXENA, 2009). Nevertheless, all these studies reported that SA improved turgidity, as observed in our experiment, where its application by wetting was particularly efficient at maintaining turgor pressure. As such, it can be inferred that the efficiency of SA in plants under salt stress may be due to its effect in conserving seedling turgidity, which is associated with increased activation of the antioxidant system, decreasing the lipid peroxidation and membrane degradation caused by salt stress (KHAN et al., 2015).

Electrolyte leakage (EL) was similar in saline and non-saline treated seedlings, except for wetting with SA, which reduced EL by $18.1 \%$ in seedlings exposed to salt stress when compared to non-saline conditions (Figure 2D). Different authors have reported that salinity reduces the stability of cell membranes (ZHU et al., 2008; HAYAT et al., 2012). Tuna et al. (2007) studied tomato plants exposed to salinity and found an increase in electrolyte leakage, decreasing membrane stability. Zhu et al. (2008) reported that salinity increased cell membrane permeability in cucumber plants, evident in the rise in electrolyte leakage. However, in our study, cell membranes remained uncompromised in bell pepper seedlings under salt stress treated with SA, particularly via wetting, which can be attributed to the stable relative water content. Other investigations have also found that SA decreased electrolyte leakage in canola under salt stress (HAYAT et al., 2012) and tomato plants exposed to heat stress (JAHAN et al., 2019).

As such, it is suggested that the bell pepper seedlings treated with SA in the present study, regardless of application method, exhibited less accumulation of toxic ions, especially $\mathrm{Na}^{+}$, and stable $\mathrm{K}^{+}$ion levels, which led to a stable $\mathrm{Na}^{+} / \mathrm{K}^{+}$ ratio. This corroborates the findings of Fayez and Bazaid (2014) and Jini and Joseph (2017), who reported that SA decreased $\mathrm{Na}^{+}$accumulation and increased $\mathrm{K}^{+}$in plants under salt stress. These results are likely associated with lower electrolyte leakage in plants under salt stress treated with $\mathrm{SA}$, since Costa et al. (2011) found that a rise in $\mathrm{K}^{+}$ ion leakage from plant tissue exposed to stress compromised the integrity of cell membranes, which lowered the $\mathrm{Na}^{+} / \mathrm{K}^{+}$ratio.

The shoot length (SL) of seedlings only varied under saline conditions, declining by $36.7 \%$ in relation to the non-saline treatment (Figure $3 A)$, whereas radicle length ( $R L$ ) was lower under salt stress. Wetting with SA reduced RL by around $28.1 \%$ in non-saline conditions and mitigated salt stress by $29 \%$ when compared to the other methods (Figure 3B). Similarly, total seedling length (TSL) was lower under salt stress than nonsaline conditions. In the absence of salinity, wetting with SA decreased TSL by $20.1 \%$ when compared to the other application methods, but rose slightly under salt stress, with values around $13.1 \%$ higher (Figure 3C). 
Figure 3. Shoot length (A), radicle length (B), total seedling length $(C)$, shoot dry weight (D), radicle dry weight (E) and total seedling dry weight $(F)$ in bell peppers submitted to different salicylic acid application methods and $\mathrm{NaCl}$ concentrations. IW: immersion in water, ISA: immersion in salicylic acid, WW: wetting with water, SW: wetting with $\mathrm{NaCl}$, WSA: wetting with salicylic acid and SW+AS: wetting with $\mathrm{NaCl}$ and salicylic acid. Vertical bars in the columns represent the standard error $(n=4)$. Different upper case letters indicate significant differences between $\mathrm{NaCl}$ concentrations within each method and lower case letters significant differences between methods within each saline concentration. Campina Grande-PB, Brazil, 2019.
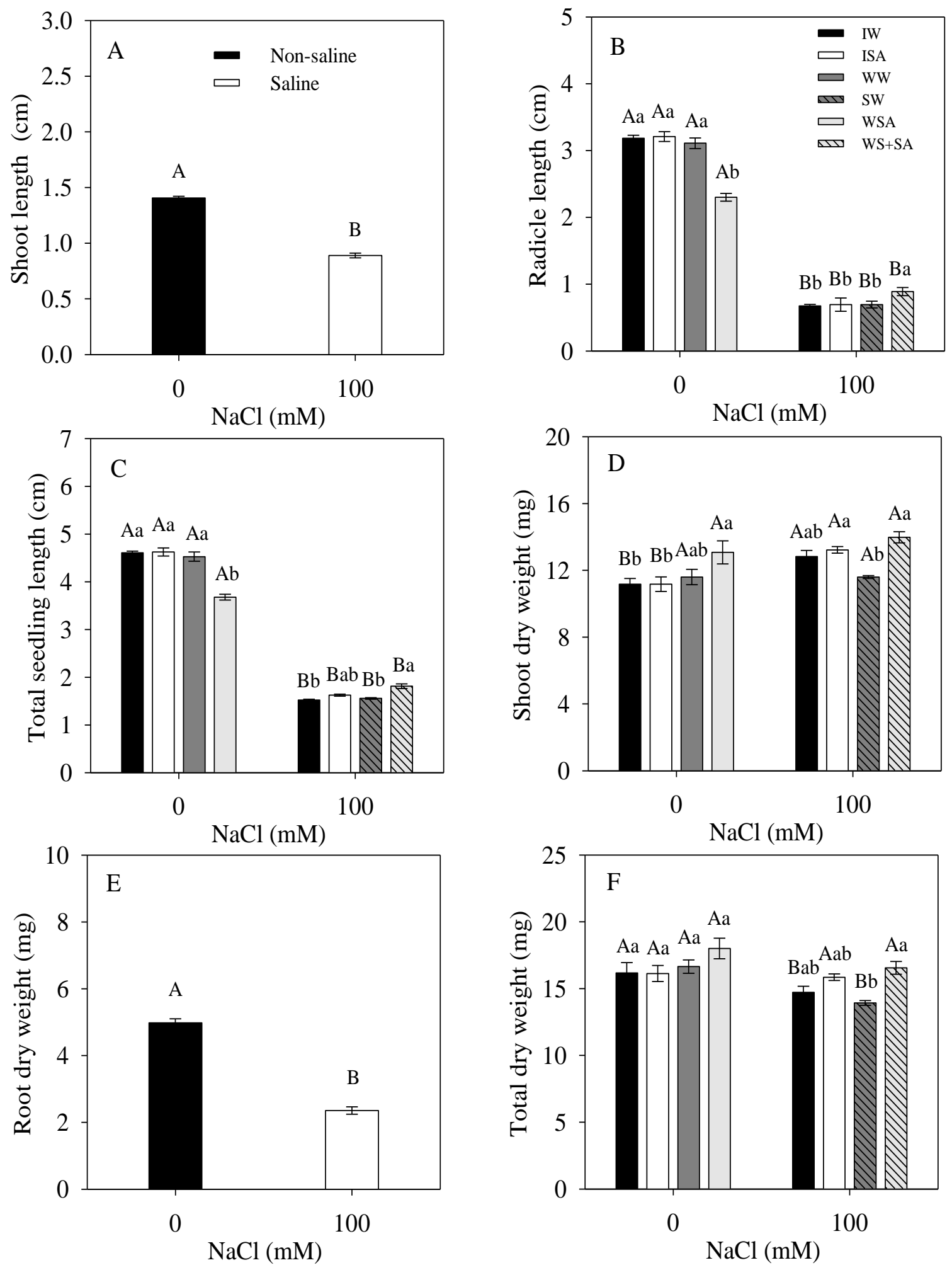
Salt stress imposed with $100 \mathrm{mM}$ of $\mathrm{NaCl}$ drastically reduced the length of bell pepper shoots, as observed in lentil (MISRA; SAXENA, 2009) and rice seedlings (JINI; JOSEPH, 2017), and roots, albeit less significantly. Salicylic acid application via wetting without salt stress inhibited root shortening, as reported in rice seedlings (JINI; JOSEPH, 2017). However, in canola plants, SA increased root length (RL) under salt stress 30 days after planting, suggesting that the exposure time to SA may influence mechanisms other than germination and seedling growth.

Shoot dry weight (SDW) varied between saline and non-saline treatments, except for wetting instead of seed immersion (Figure 3D), but obtained similar values for wetting with SA. Additionally, treatments with SA under saline conditions produced better results than those without salicylic acid. Radicle dry weight (RDW) only differed between the saline treatments, with a reduction of about $52.8 \%$ at $100 \mathrm{mM}$ of $\mathrm{NaCl}$ (Figure 3E).

Total seedling dry weight (TDW) declined under salt stress only for treatments without SA. Salicylic acid application by seed immersion and wetting improved TDW by 7.6 and 18.9\%, respectively, under saline conditions (Figure 3F). Applying $\mathrm{SA}$ in the saline treatments also increased total seedling length, shoot dry weight (SDW) and total dry weight when compared to non-saline conditions. However, the trait that most benefitted from salicylic acid was SDW, as demonstrated in principal component analysis. A similar increase was reported for rice seedling growth with SA application (JINI; JOSEPH, 2017), as well as lentil (MISRA; SAXENA, 2009) and canola growth and dry weight (HAYAT et al., 2012) under salt stress.

Vigor index I (VI-I) was higher in the nonsaline than saline treatment. In the absence of salt stress, VI-I declined when seeds were wetted with salicylic acid, but increased under salinity for the same technique, despite not differing from seed immersion (Figure 4A). There was a slight decline in vigor index II (VI-II) between saline and non-saline treatments. Under salt stress, VI-II values were $30.1 \%$ higher for wetting with SA in relation to wetting with salt alone, but $8.9 \%$ greater for immersion in SA when compared to only immersing seeds in water (Figure 4B).

Figure 4. Vigor indices I (A) and II (B) in bell pepper seedlings submitted to different salicylic acid application methods and $\mathrm{NaCl}$ concentrations. IW: immersion in water, ISA: immersion in salicylic acid, WW: wetting with water, SW: wetting with $\mathrm{NaCl}$, WSA: wetting with salicylic acid and SW+AS: wetting with $\mathrm{NaCl}$ and salicylic acid. Vertical bars in the columns represent the standard error $(n=4)$. Different upper case letters indicate significant differences between $\mathrm{NaCl}$ concentrations within each method and lower case letters significant differences between methods within each saline concentration. Campina Grande-PB, Brazil, 2019.
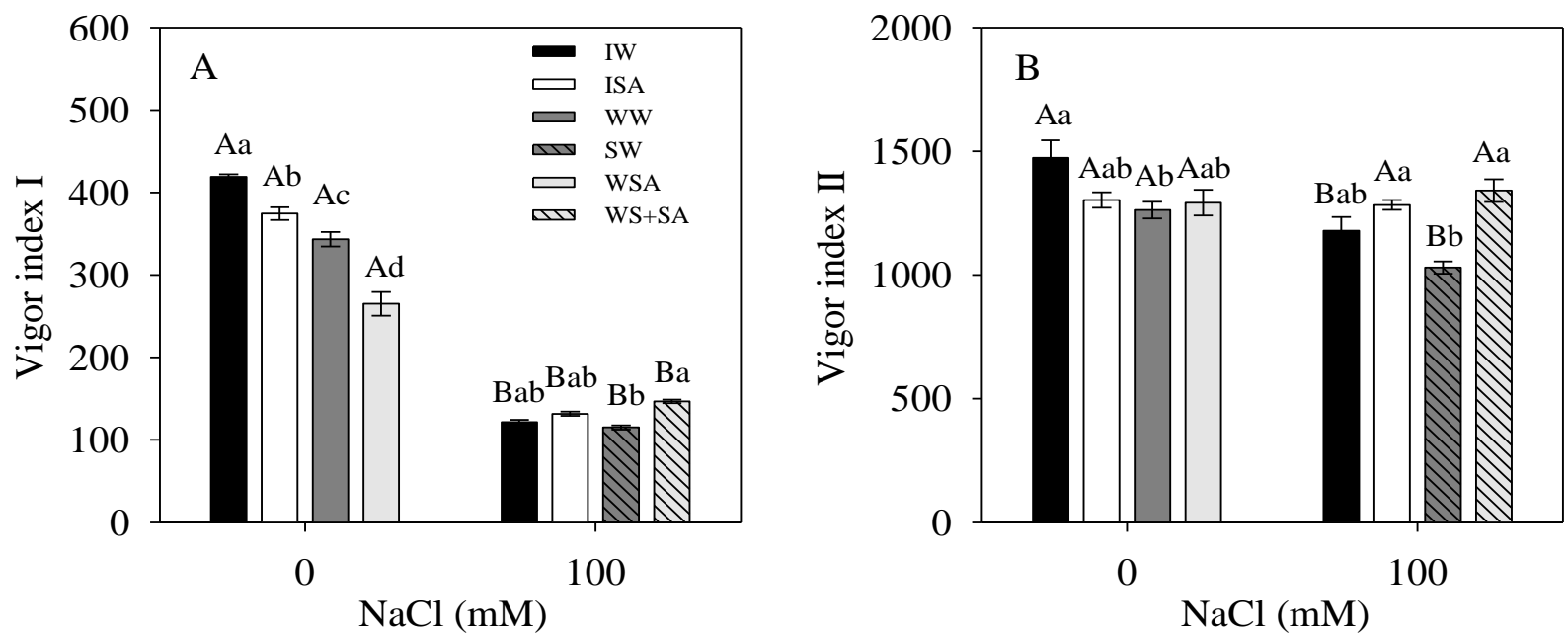
During germination and seedling establishment, the length of the different seedling parts and vigor index I were the variables that most contributed to the formation of PC1, with a variation of $54.5 \%$ (Figure $5 \mathrm{~A}$ ). Principal component analysis (PCA) showed a clustering tendency between saline conditions, with the formation of one saline and one non- saline group (Figure 5B). Analysis of the clusters demonstrated that SDW was related to the separation of treatments with salicylic acid under saline conditions, while EL was associated with salt stress without $S A$, indicating that these variables contributed most to the clustering of treatments involving salinity.

Figure 5. Principal component analysis (PCA) biplot displaying the germination and seedling establishment characteristics of bell pepper seedlings submitted to different salicylic acid application methods and $\mathrm{NaCl}$ concentrations. IW: immersion in water; ISA: immersion in salicylic acid; WW: wetting with water; and WSA: wetting with salicylic acid. 0 and 100 represent $\mathrm{NaCl}$ concentrations of 0 and $100 \mathrm{mM}$. Campina Grande-PB, Brazil, 2019.

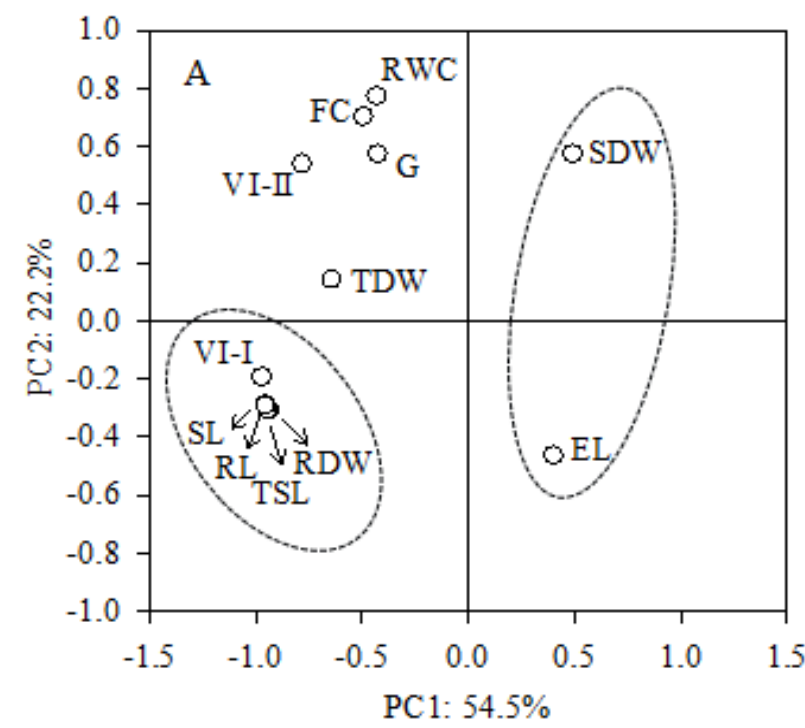

The attenuating effects of SA on the growth and biomass production of seedlings under stress are reflected in their vigor, evident in vigor indices I and II. Vigor index I improved with SA application, particular via wetting, whereas vigor index II was independent of the application technique used. Similarly, in wheat seedlings submitted to $100 \mathrm{mM}$ of $\mathrm{NaCl}$, applying $100 \mu \mathrm{M}$ of SA via wetting increased vigor by $26 \%$ compared to $\mathrm{NaCl}$ alone (ALAMRI et al., 2018). Vigor indices are important indicators, particularly in seedlings germinated under stress or the effect of germination inducers, evident in the increased vigor observed in tomatoes treated with nano-SiO ${ }_{2}$ (SIDDIQUI; AL-WHAIBI, 2014) and hydro-primed cotton seeds (NAGUIB, 2019).

\section{Conclusions}

Salicylic acid reduced the germination and radicle length of bell pepper seedlings under nonsaline conditions, especially when applied via wetting. However, under salt stress, SA improved

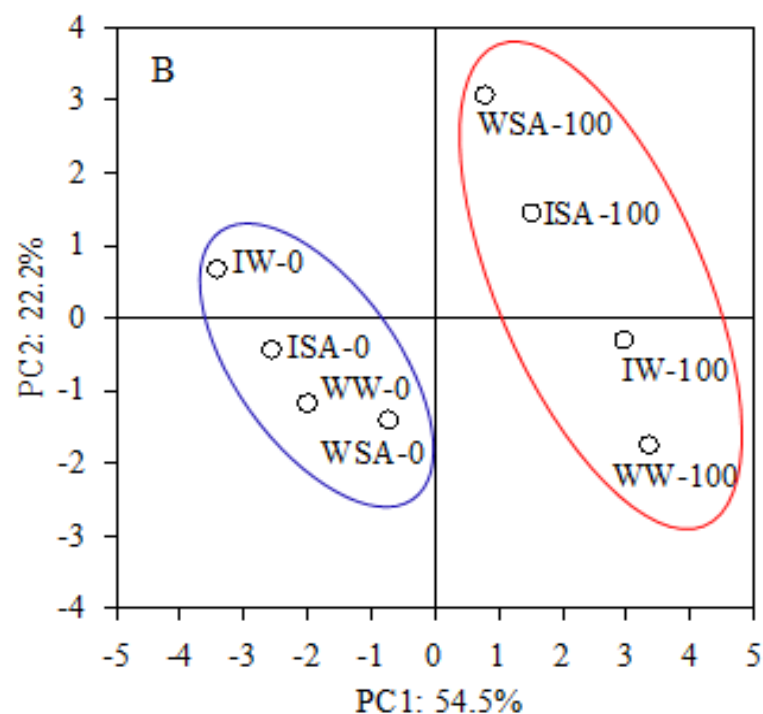

the seedling adaptation to these conditions by decreasing electrolyte leakage, maintaining turgidity and increasing shoot length and total dry weight, thereby increasing vigor. Notably, SA application via wetting was more efficient than immersion under saline conditions, although both methods had a similar effect on shoot dry weight and vigor.

\section{Acknowledgement}

To Conselho Nacional de Desenvolvimento Científico e Tecnológico (CNPq) (Grant PDJ PostDoctoral Junior 153397/2018-7 to first author).

\section{References}

ALAMRI, S.A.; SIDDIQUI, M.H.; AL-KHAISHANI, M.Y.; ALI, H.M. Response of salicylic acid on seed germination and physio-biochemical changes of wheat under salt stress. Acta Scientiarum, v.2, n.5, p.36-42, 2018. 
BARTELS, D.; SUNKAR, R. Drought and salt tolerance in plants. Critical Reviews in Plant Sciences, v.24, n.1, p.23-58, 2005. https://doi.org/10.1080/07352680590910410

BRASIL. Ministério da Agricultura, Pecuária e Abastecimento. Regras para análise de sementes. Brasília: Secretaria de Defesa Agropecuária, 2009. 395p.

CHU, X.T.; FU, J.J.; SUN, Y.F.; XU, Y.M.; MIAO, Y.J.; $\mathrm{XU}$, Y.F.; HU, T.M. Effect of arbuscular mycorrhizal fungi inoculation on cold stressinduced oxidative damage in leaves of Elymus nutans Griseb. South African Journal of Botany, v.104, p.21-29, 2016. http://10.1016/j.sajb.2015.10.001

COSTA, A.S.; NOGUEIRA, L.C.; DOS SANTOS, V.F.; FINGER, F.L.; CAMARA, T.R.; LOGES, V.; WILLADINO, L. Characterization of symptoms of senescence and chilling injury on inflorescences of Heliconia bihai (L.) cv. Lobster Claw and cv. Halloween. Postharvest Biology and Technology, v.59, n.1, p.103-109, 2011. http://10.1016/i.postharvbio.2010.08.015

FAYEZ, K.A.; BAZAID, A.S. Improving drought and salinity tolerance in barley by application of salicylic acid and potassium nitrate. Journal of the Saudi Society of Agricultural Sciences, v.13, n.1, p.45-55, 2014. http://10.1016/j.jssas.2013.01.001

GROVER, O.; GAUR, I.; MITRA, J.; PAUL, P.K. Effect of Salicylic Acid on Germination of Phaseolus vulgaris and Cicer arietinum Under Salt Stress. Trends in Bioscience, v.8, n.16, p.4142-4147, 2015.

HAYAT, S.; MAHESHWARI, P.; WANI, A.S.; IRFAN, M.; ALYEMENI, M.N.; AHMAD, A. Comparative effect of 28 homobrassinolide and salicylic acid in the amelioration of $\mathrm{NaCl}$ stress in Brassica juncea L. Plant Physiology Biochemistry, v.53, p.61-68, 2012. http://10.1016/i.plaphy.2012.01.011

HUSEN, A.; IQBAL, M.; SOHRAB, S.S.; ANSARI, M.K.A. Salicylic acid alleviates salinity-caused damage to foliar functions, plant growth and antioxidant system in Ethiopian mustard (Brassica carinata A. Br.). Agriculture and Food Security, v.7, $\quad$.1, p.44, 2018. https://doi.org/10.1186/s40066-018-0194-0
JAHAN, M.S.; WANG, Y.; SHU, S.; ZHONG, M.; CHEN, Z.; WU, J.; SUN, J.; GUO, S. Exogenous salicylic acid increases the heat tolerance in Tomato (Solanum lycopersicum L.) by enhancing photosynthesis efficiency and improving antioxidant defense system through scavenging of reactive oxygen species. Science Horticulturae, v.247, p.421-429, 2019. https://doi.org/10.1016/i.scienta.2018.12.047

JAYAKANNAN, M.; BOSE, J.; BABOURINA, O.; RENGEL, Z.; SHABALA, S. Salicylic acid in plant salinity stress signalling and tolerance. Plant Growth Regulation, v.76, n.1, p.25-40, 2015. https://doi.org/10.1007/s10725-015-0028-z

JINI, D.; JOSEPH, B. Physiological mechanism of salicylic acid for alleviation of salt stress in rice. Rice Science, v.24, n.2, p.97-108, 2017. https://doi.org/10.1016/j.rsci.2016.07.007

KHAN, M.S.; AKTHER, T.; ALI, D.M.; HEMALATHA, $S$. An investigation on the role of salicylic acid alleviate the saline stress in rice crop (Oryza sativa L.). Biocatalysis and Agricultural Biotechnology, v.18, p.101027, 2019. http://10.1016/i.bcab.2019.101027

KHAN, M.I.R.; FATMA, M.; PER, T.S.; ANJUM, N.A.; KHAN, N.A. Salicylic acid-induced abiotic stress tolerance and underlying mechanisms in plants. Frontiers in Plant Science, v.6, p.462, 2015. https://doi.org/10.3389/fpls.2015.00462

SHRIVASTAVA, P.; KUMAR, R. Soil salinity: A serious environmental issue and plant growth promoting bacteria as one of the tools for its alleviation. South African Journal of Botany, v.22, p.123-131, 2015. http://10.1016/j.sjbs.2014.12.001

LOTFI, N.; SOLEIMANI, A.; VAHDATI, K.; ÇAKMAKÇI, R. Comprehensive biochemical insights into the seed germination of walnut under drought stress. Scientia Horticulturae, v.250, p.329-343, 2019. https://doi.org/10.1016/j.scienta.2019.02.060

MAGUIRE, J.D. Speed of germination-aid in selection and evaluation for seedling emergence and vigor. Crop Science, v.2, n.1, p.176-177, 1962.

https://doi.org/10.2135/cropsci1962.0011183X0 $\underline{00200020033 \mathrm{x}}$ 
MISRA, N.; SAXENA, P. Effect of salicylic acid on proline metabolism in lentil grown under salinity stress. Plant Science, v.177, n.3, p.181-189, 2009. https://doi.org/10.1016/j.plantsci.2009.05.007

NAGUIB, D.M. Metabolic profiling during germination of hydro primed cotton seeds. Biocatalysis and Agricultural Biotechnology, v.17, p.422-426, 2019. https://doi.org/10.1016/i.bcab.2018.12.025

SIDDIQUI, M.H.; AL-WHAIBI, M.H. Role of nano$\mathrm{SiO} 2$ in germination of tomato (Lycopersicum esculentum seeds Mill.). Saudi Journal of Biological Sciences, v.21, n.1, p.13-17, 2014. https://doi.org/10.1016/i.sjbs.2013.04.005

TONEL, F.R.; MARINI, P.; BANDEIRA, J.D.M.; MORAES, D.M.D.; AMARANTE, L.D. Salicylic acid: physiological and biochemical changes in seeds and maize seedlings subjected to salt stress. Journal Seed Science, v.35, n.4, p.457-465, 2013. https://doi.org/10.1590/S2317$\underline{15372013000400007}$

TUNA, A.L.; KAYA, C.; ASHRAF, M.; ALTUNLU, H.; YOKAS, I.; YAGMUR, B. The effects of calcium sulphate on growth, membrane stability and nutrient uptake of tomato plants grown under salt stress. Environmental and Experimental Botany, v.59, n.2, p.173-178, 2007. https://doi.org/10.1016/i.envexpbot.2005.12.007

WILLADINO, L.; CAMARA, T.R. Tolerância das plantas à salinidade: aspectos fisiológicos e bioquímicos. Enciclopédia Biosfera, v.6, n.11, p.123, 2010.

ZHU, J.; BIE, Z.; LI, Y. Physiological and growth responses of two different salt-sensitive cucumber cultivars to $\mathrm{NaCl}$ stress. Soil Science Plant Nutrition, v.54, n.3, p.400-407, 2008. https://doi.org/10.1111/i.1747-

0765.2008.00245.x 